\title{
Analysis of Content on the News of the Infrastructure Development of Toll Road Padang-Pekanbaru
}

\author{
$1^{\text {st }}$ Nora Eka Putri ${ }^{1}, 2^{\text {nd }}$ Muhammad Fauzan Harza ${ }^{2}$ \\ \{noraekaputri@fis.unp.ac.id ${ }^{1}$, muhammadfauzanharza@gmail.com ${ }^{2}$ \} \\ Public Administration Department, Universitas Negeri Padang, Indonesia ${ }^{1}$, Linguistics, Faculty of \\ Humanities, Andalas University, Indonesia ${ }^{2}$
}

\begin{abstract}
Construction of infrastructure transportation such as toll roads in Indonesia remains a burden. This is due to the construction of roads that impact people's economic development, social life, and environmental sustainability. Plural found that the construction of toll roads caused conflict. The most significant problem is the land procurement process for toll road construction, including the construction of toll roads in West Sumatra that are more unique due to the land of Ulayat. This research aims to identify the development of Padang-Pekanbaru toll road building by online news portals of a specific period. Research methods are carried out with a quantitative approach with content analysis methods. The results explained that the development of Padang-Pekanbaru toll road is considered more dominant news from the government, and developers (75\%) than news from the community (25\%), and the category of content analysis is inference analysis.
\end{abstract}

Keywords: Content analysis, news, development, toll roads

\section{Introduction}

Infrastructure development in the Sustainable Development Goals (SDGs) includes economic, legal, and governance objectives. In West Sumatra, road transportation infrastructure development, especially toll roads, is experiencing problems. The problem is the political will aspect of stakeholders between local governments and the central government that is relatively difficult to coordinate to realize toll road infrastructure development and sustainable development. The target of toll road infrastructure development in West Sumatra has not been achieved significantly, while the construction of the same toll road infrastructure in other regions is relatively successful implemented by the government, due to the clarity of coordination of local and central governments, for example in Aceh and other regions on the island of Sumatra.

In West Sumatra, the construction of padang-pekanbaru toll road consists of five sections, namely Padang-Sicincin, Sicincin-Payakumbuh, Payakumbuh-Pangkalan-PangkalanBangkinang, and Bangkinang-Pekanbaru. Padang-Pekanbaru toll road can save costs, both power and fuel used. Also, it can reduce the load distance that is usually traveled in 7-8 hours to 3-4 hours (source from http://m.bisnis.com/sumatra/ padang pariaman regent Ali Mukhni greeting karib March 18, 2019 at 11:20 am). 
However, that opinion does not represent public opinion, because they think that the toll road makes their economic activity decrease from the existence of the toll road. The community does not accept the price of land and land damages by The Appraisal Team. The result of the pricing by the Appraisal Team is well below the average selling price of the land. The public considers that the price of compensation is still too low where the process of indemnity in any assessment by the appraisal in the land price (Bisnis.com, January 2019/around on March 15, 2019). Whereas in accordance with Law No. 2 of 2012 on Land Procurement for the Public Interest article 1 paragraph 11, the assessor is an individual who conducts an independent and professional assessment where the practice permit is assessed by the Minister and Finance of one of the original institutions of the Land Agency for the value or price of land objects. There is no mistaking the appraisal team's assessment of the price of compensation, but in fact, the price already done by the appraisal team becomes polemical in its communities whose land is affected by the construction of toll roads. The information respects the above concerns over news through mass media coverage, both print media and online. However, the news has not explained the information that is balanced between the opinion of the government and the opinion of the public. Therefore, it is necessary to analyze the content of mass media coverage that preaches the construction of Padang- Pekanbaru toll road, especially Padang- Sicincin section.

The research was conducted for the police chief of Padang-Pekanbaru toll road development by online news portal https://e-paper.hariansinggalang.co.id/ from January to August 2020.

\section{Literature Review}

1. Content Analysis

Content analysis is a research technique for replicating able and valid conclusions from the text (or other meaningful material) into the context of its use [1]. Content can be words, meanings, images, symbols, ideas, themes, other communication messages. While the text of any written, visual, or spoken form can be books, newspapers, magazine articles, advertisements, speech scripts, documents, films, music lyrics (Neuman, 2011: 361).

\section{News}

In the English Dictionary by W.J.S. Poerwodarminta, the news is interpreted as 'news or news.' While in Balai Pustaka's Great Dictionary of Bahasa Indonesia, the news meaning is clarified as 'a report on a warm event or event'. So the news is associated with events or events that occur. News is information that deserves to be presented to the public. News that is considered worthy is information that is factual, actual, accurate, objective, necessary, and of course, attracts public attention, published through mass media [3].

Types of news (Utami, 2018)[3]

a. Hard News is news about events that are considered important to society, whether as individuals, groups, or organizations. Hard News is classified as live news, such as straight news and spot news. The actuality is an important element of live news. Long-standing events or events are of no value to living news. 22 Actuality is not just about time but something new to know or discover, for example, a new way, a new idea of discovery. 
b. Soft News is news that is not related to actuality but appeals to its viewers. It is often referred to as a feature or human interest. This kind of news is often more focused on things that can amaze or amaze viewers. In other words, soft news directly touches the reader's emotions, such as touch, excitement, fury, cuteness, anger, and others.

c. In-depth News is a news story that focuses on events or facts and or opinions that contain the value of the news. This news story links to a news report and reflects the problem in a broader context. This type of news is comprehensive news, interpretative news, and investigative news.

\section{Construct of Category News}

Category construction is a kind of tool used to explore problems in research. The category created serves to sort the contents of the message expressed into an overview (in the form of data) that can be analyzed to answer the proposed problem [4]. Flanagin and Metzger use multidimensional concepts to measure media credibility, namely believability, accuracy, bias, and completeness [3]. The credibility of a news story can also be analyzed using the Accuracy category construct (accurate, meticulous, and meticulous), Universality; fairness (honest and fair), Humanity (humanitarian value, Immediate), soon [3].

This research will analyze the news about the construction of Padang- Sicincin toll road in West Sumatra using the concept of news credibility, as follows:

Table 1. Concept of Operationalization

\begin{tabular}{|c|c|c|c|}
\hline Dimensions & Sub-dimensions & Analysis Unit & Category \\
\hline \multirow[t]{2}{*}{ Accuracy } & Truth & Factual & $\begin{array}{l}\text { Sociological facts } \\
\text { Legal facts }\end{array}$ \\
\hline & News completeness & $5 \mathrm{~W}+1 \mathrm{H}$ & $\begin{array}{l}\text { Complete } \\
\text { Incomplete }\end{array}$ \\
\hline \multirow[t]{2}{*}{ Universality } & Public interest & $\begin{array}{l}\text { Development } \\
\text { Implementation }\end{array}$ & $\begin{array}{l}\text { Support } \\
\text { Not Supporting }\end{array}$ \\
\hline & Similarities & See from all sides & $\begin{array}{l}\text { One side } \\
\text { Both sides } \\
\text { Multi-sided }\end{array}$ \\
\hline \multirow[t]{2}{*}{ Fairness } & Trustworthy & $\begin{array}{l}\text { Comply with applicable } \\
\text { rules and norms }\end{array}$ & $\begin{array}{l}\text { Comply with } \\
\text { Disobeying }\end{array}$ \\
\hline & Impartiality & Neutral & $\begin{array}{l}\text { News sensations } \\
\text { Evaluative news } \\
\text { Steriotip news }\end{array}$ \\
\hline \multirow[t]{2}{*}{ Humanity } & Equality & Community & $\begin{array}{l}\text { Development Subjects } \\
\text { Development Objects }\end{array}$ \\
\hline & Freedom of speech & Community Participation & $\begin{array}{l}\text { There are } \\
\text { None } \\
\text { Do not Care }\end{array}$ \\
\hline
\end{tabular}




\section{Toll Road Infrastructure Development}

Infrastructure is an essential service for the community, for example in the areas of energy, transportation (roads; bridges; airports; ports, railways, etc.), water, telecommunications, social infrastructure (hospitals, prisons, museums, schools, and other government accommodation [5]. Infrastructure is an essential aspect of development. Infrastructure as one of the development parameters consists of physical infrastructure and social infrastructure. An example of such infrastructure is the field of transportation; health, education, energy, and more (Harris, Riley, Dawson, Friel, \& Lawson, 2018; Kumari, Anita; Sharma, 2017; Melo, Graham, \& Brage-ardao, 2013; Szeto \& Chen, 2017.

Transportation is an essential aspect of the development of a Country's economy. Transportation is the right of every citizen[10]. Transportation infrastructure is related to the community's welfare because, through transportation infrastructure, the wheels of the community economy become more efficient and effective. Among those included in the transport infrastructure are [11] Road transport; Railway transport; air transport; air transport control; waterway transport / maritime transport.

Toll road construction aims to facilitate mobilization access for the community and can also reduce production costs in economic activities. Toll road utilization can increase time efficiency and financing for the community in carrying out daily activities, so that toll road will indirectly be able to open and develop areas that can improve the economy of the community [12]. In addition to efficiency factors, toll road construction is also useful in realizing sustainable development. Development targets implemented by the government to prosper the community will be realized because transportation access such as roads will open up opportunities for people in the economy, education, health, social, and culture.

\section{Methodology}

This research uses a quantitative research approach with a method of content analysis, namely a research technique to make a replica table and valid conclusions from the text (or other meaningful material) into the context of its use [12]. The analysis of content in this study is against online media https:hariansinggalang.co.id/ because the online media is one of the largest online media in West Sumatra and existed for a long time, then also the coverage of its coverage of West Sumatra and Nasional. So the selection of online media is considered relevant to identify the news of toll road construction in West Sumatra (Construction of Padang- Sicincin toll road). The reporting period to be identified is from January to August 2020.

\section{Finding and Discussion}

News on Media Online https:.www.hariansinggalang.co.id

Online media Harian Singgalang.co.id is part of the Harian Singgalang newspaper. the newspaper is a local newspaper of West Sumatra that has been published for a long time and has a relatively large readership spread across the province of West Sumatra. Hariansinggalang.co.id is an online media portal that provides information about various aspects of life, such as political, economic, social, development, and so on with coverage of west Sumatra province as well as Indonesia. Related to the research conducted on the analysis 
of the content of Padang- Pekanbaru toll road infrastructure development from January to August 2020, the data on the news is obtained as follows:

Table 2. Recapitulation of Padang Toll Road Infrastructure Development- Pekanbaru in Online Media Hariansinggalang.co.id January to August 2020

\begin{tabular}{cll}
\hline No & \multicolumn{1}{c}{ Day/ Time published } & \multicolumn{1}{c}{ News Headlines } \\
\hline 1 & Saturday, 29/02/2020/ & Jika Ditolak juga Alihkan Saja Tol ke Supayang \\
& 12.24 WIB & Situjuah, Pucuk Adat dan Nagari Siap Terima \\
2 & Friday, 21/02/2020/ 18.00 & Kapolda Sumbar Tinjau Pelaksanaan Proyek Tol \\
& WIB & Padang- Pekanbaru \\
3 & Thursday/ 11/02/2020/ & Tol Padang-Pekanbaru Ganti Trase, Ruas Duku- \\
& Sicincin Batal \\
4 & Sunday/ 14/06/2020/ & Pemuda Sumbar Ajak Semua Pihak Dukung \\
& 21.42 WIB & Percepatan Pembangunan Tol Padang- Pekanbaru \\
\end{tabular}

Source: processed by researchers, 2020

\section{News Credibility}

Based on the results of the study using the analysis of the constructed category of credible news about the construction of Padang- Pekanbaru toll road infrastructure, it is known that:

1. Accuracy is to see and correct the news. From the news data, it is known that all news is fact and contains the completeness of the news element. The fact of the sociological aspect is that the people of West Sumatra approved the construction of toll roads because they realize that the development was carried out by the government to improve the welfare of the community. But there are concerns in some communities if their land is used by the government to build roads, what about the replacement system, then it also has an impact on people's lifestyles that tend to be different from before the construction of toll roads. While the fact of the news from the legal aspect is the government's compliance with the rules to carry out toll road construction that follows the established planning, even socialization through the news in various mass media is also carried out systematically. However convincing the public is not easy, as evidenced in the news in hariansinggalang.co.id there are still people who refuse to build toll roads in his area and then diverted to other areas.

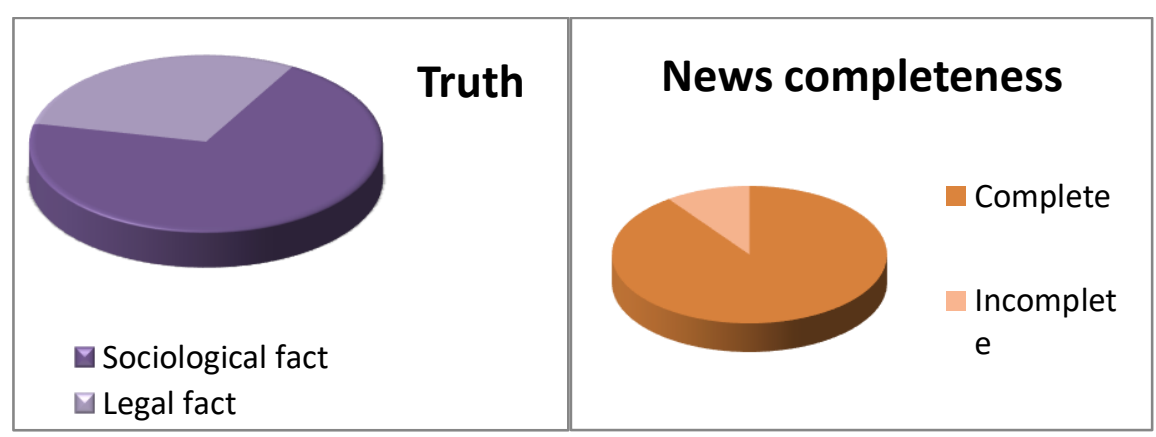

Figure 1. Percentage of content analysis of accuracy category 
2. Universality ( General apply), the meaning is that the news is information for all parties and public interest in realizing good development. In hariansinggalang.co.id it is known that the news about the construction of toll roads in West Sumatra from January to August 2020 is considered very little, namely, only four news, even though the toll road development process continues so that, it is assessed that this news is not yet thorough, it results in information being read by an unsustainable audience, even though the construction of toll roads in west Sumatra region is significant to improve people's mobility and also economic acceleration.
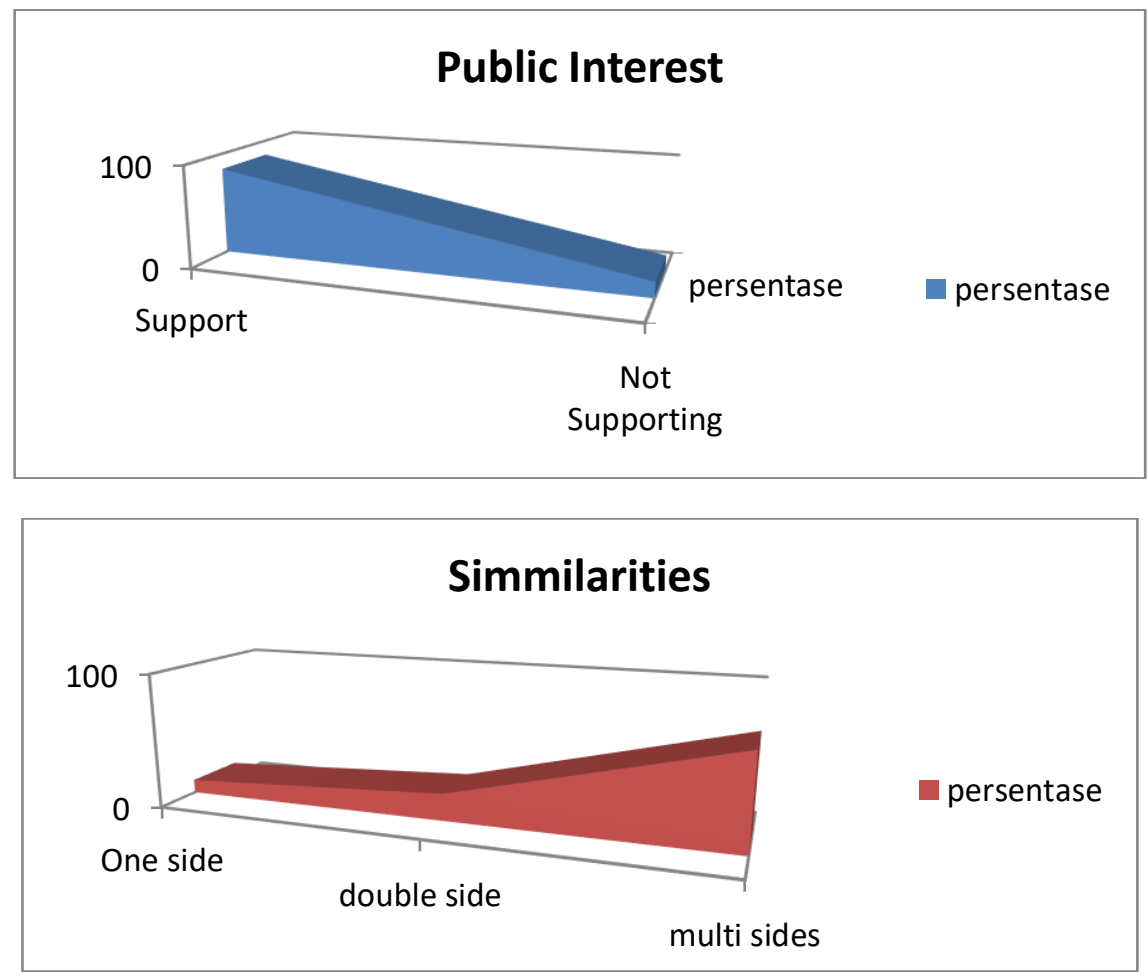

Figure 2. Percentage of content analysis of universality category

3. Fairness ( honest and fair), is that the news delivered is honest by the data and facts collected and not because of certain interests. Meanwhile, the fairness of the intent is that the information submitted must be neutral and impartial so that in the news displayed, it can be seen that a news story is written with proportionate data from one or more parties written in the news. Related to the construction of Padang Pekanbaru toll road, news aired on online media hariansinggalang.co.id is quite neutral because there are opinions from the public and also from the local government, but there is little opinion from central government representatives who are leading sectors of PadangPekanbaru toll road development such as the Ministry of PU PR and also BPN as a party directly involved in the location determination and determination of the value of land and land compensation. Then another aspect that becomes the accuracy of this news assesses that throughout January to August 2020, news about the construction of the Padang-Pekanbaru toll road is very little reported by hariansinggalang.co.id even 
though the construction of toll roads is still in the process of development carried out by the government, including the progress of the implementation of toll road construction is not reported by the hariansinggalang.co.id so that the information obtained by the public is not comprehensive and impressed that this news is a category of sensational news that arises because there is momentum. It should be news of the construction of this toll road to be evaluative news and can be followed by the community at every stage of its development.

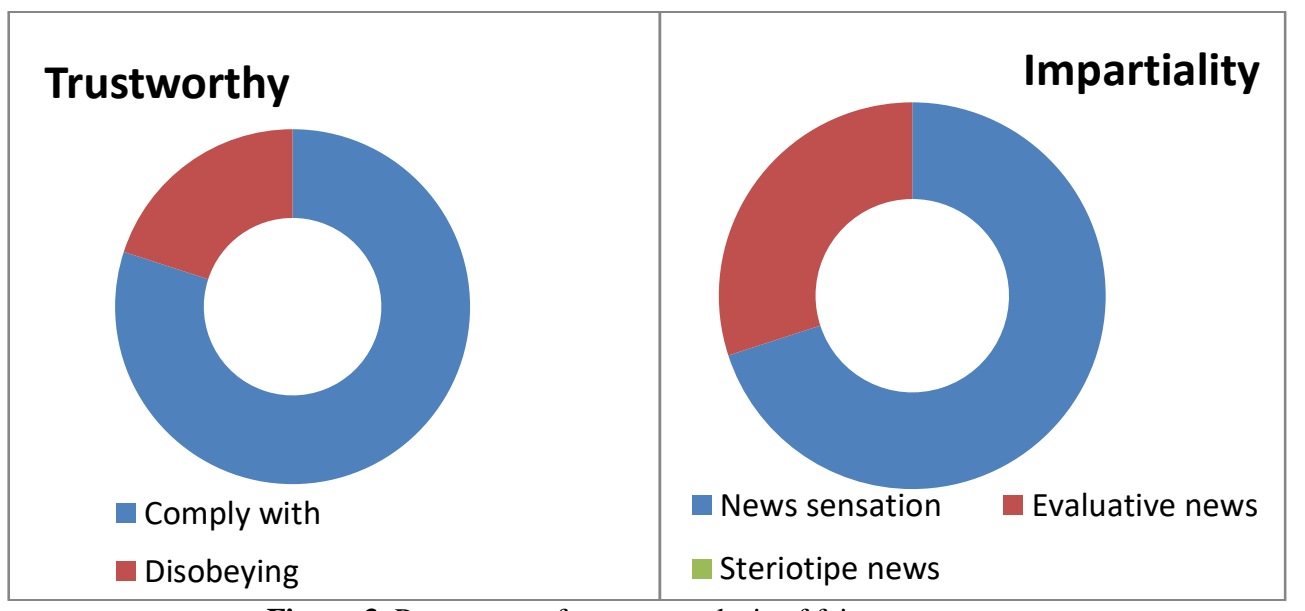

Figure 3. Percentage of content analysis of fairness category

4. Humanity (human values), is related to equality and freedom of speech by the people. The news must be equal and also support community participation. Related to research conducted based on news data on online media hariansinggalang.co.id, of the four news over three out of four $(75 \%)$ the news that is the subject of the headline is the government and only one (25\%) from news headlines whose subject is public. So the news is judged only to meet the complaints and doubts of the community towards the construction of Padang- Pekanbaru toll road. From the news is considered that the information submitted through the news is only to convey complaints and doubts from the public over the construction of the Padang-Pekanbaru toll road. Then relatively little news that explains the importance of toll road construction and its benefits for the community, even though the construction of the toll road has been physically started from Nagari Kasang Padang Pariaman Regency (Ayu \& Nora Eka Putri, 2020), and is not reported by hariangsinggalang.co.id throughout January to August 2020 


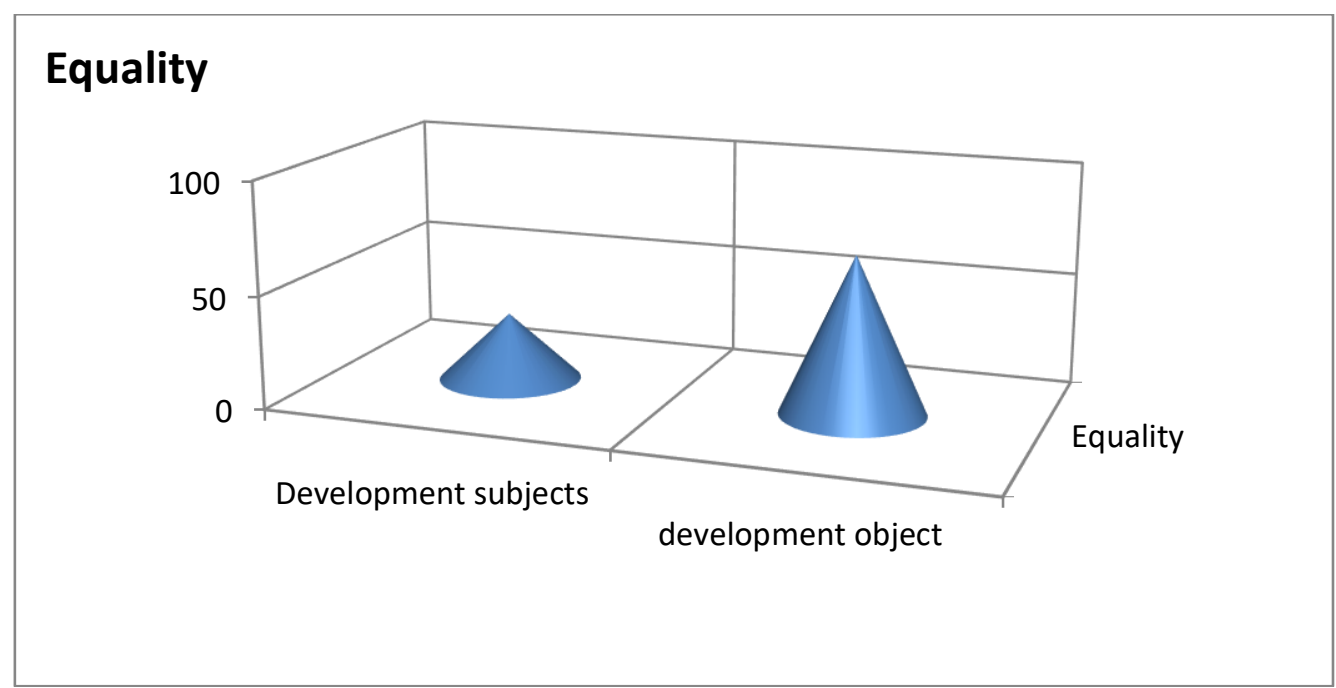

Figure 4.6 Percentage of content analysis of humanity category

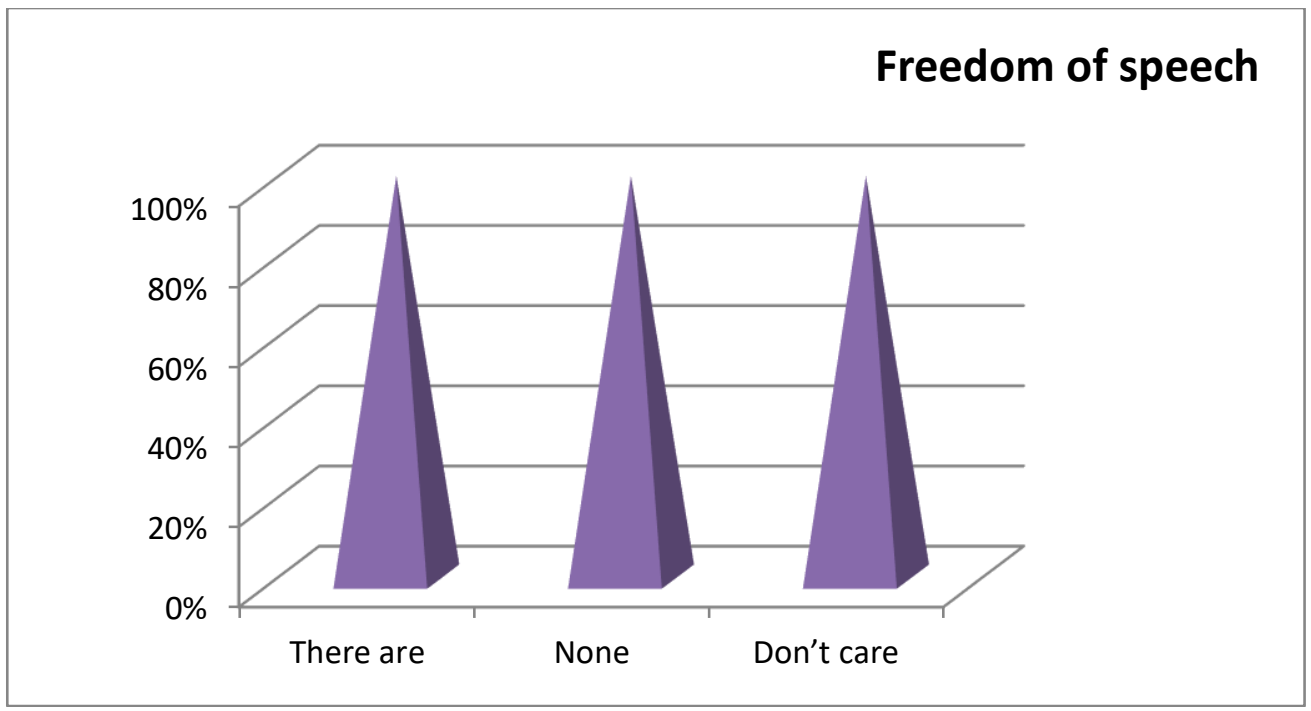

Figure 4. Percentage of content analysis of humanity category

Based on the category of content analysis on a news story. The news about the construction of toll road infrastructure in hariansinggalang.co.id is a form of inference content analysis that is to examine the source, audience, and effects of the content and explore why and what is the effect of a news story [14]. Based on the news about toll road construction in West Sumatra, it is known to provide information to all parties about the development carried out by the government and through the news will be known the effect caused to readers. So that through that the message that will be conveyed to the newsreader. Another effect is the trust of stakeholders to develop development that aims to improve the economy and the welfare of the 
community. Finally, there is a synergy between the government and the community in the implementation of development to create harmony in development.

\section{Conclusion}

From research on the analysis of the content of Padang-Pekanbaru toll road infrastructure development is known that based on the construct of categories consisting of accuracy; universality; fairness, and humanity, the news on hariansinggalang.co.id already doing the news quite well even though the duration of the news is relatively small and not yet comprehensive. Furthermore, based on the type of content analysis, the hariansinggalang.co.id on the construction of Padang- Pekanbaru toll road infrastructure is included in the inference category, namely delivering informative news and giving effect to its readers.

\section{References}

[1] K. Krippendorff, Emerging trends in content analysis, vol. 1, no. May. 1989.

[2] S. Stemler, "An overview of content analysis," Pract. Assessment, Res. Eval., vol. 7, no. 17, pp. 2000-2001, 2001.

[3] S. Utami, "Kredibilitas Pemberitaan Tentang Aksi Bela Islam 64 di Kompas.com," Universitas Islam Negeri Walisongo, 2018.

[4] D. Sagita, "Analisis isi, Isu penistaan Agama, dan Media Online.," in Magister Ilmu Komunikasi 1, 2016.

[5] prude homme Remy, "Evaluating the risks of public private partnerships for infrastructure projects," Int. J. Proj. Manag., vol. 20, no. 2, pp. 107-118, 2002.

[6] W. Y. Szeto and A. Chen, "Special issue on "Green urban transportation," Transp. Res. Part B Methodol., vol. 103, pp. 1-4, 2017.

[7] P. Harris, E. Riley, A. Dawson, S. Friel, and K. Lawson, “'Stop talking around projects and talk about solutions': Positioning health within infrastructure policy to achieve the sustainable development goals," Health Policy (New. York)., 2018.

[8] anil kumar Kumari, anita; sharma, "Infrastructure financing and development: A bibliometric review," Int. J. Crit. Infrastruct. Prot., vol. 16, pp. 49-65, 2017.

[9] P. C. Melo, D. J. Graham, and R. Brage-ardao, "Regional Science and Urban Economics The productivity of transport infrastructure investment: A meta-analysis of empirical evidence," Reg. Sci. Urban Econ., vol. 43, no. 5, pp. 695-706, 2013.

[10] M. Kadarisman, "Implementasi Kebijakan Sistem Transportasi Darat dan Dampaknya terhadap Kesejahteraan Sosial di Jakarta," J. Manaj. Transp. dan Logistik, vol. 02, no. 01, pp. 59-78, 2015.

[11] K. Hoterová, Z. Dvořák, and P. Blaho, "Objectification of Criteria for a Critical Infrastructure Elements in the Rail Transport Sub-sector," Transp. Res. Procedia, vol. 40, pp. 1349-1355, 2019.

[12] A. Aziz and H. Wisnu, "Pengaruh Pembangunan Jalan Tol Terhadap Perubahan Pola Dan Struktur Ruang Kawasan Sidomulyo, Ungaran Timur," J. Tek. PWK (Perencanaan Wil. Kota), vol. 3, no. 4, pp. 729-737, 2014.

[13] W. P. A. Ayu and Nora Eka Putri, "Implementasi Pembangunan Jalan Tol Ruas PadangSicincin dari Aspek Pengadaan Tanah,” J. Niara, vol. 13, no. 2, pp. 23-28, 2020.

[14] S. Rufai and C. Bunce, "World leaders' usage of Twitter in response to the COVID-19 pandemic: a content analysis," J. Public Health (Oxf)., vol. 42, Apr. 2020. 